\title{
Commentary Identification of murine mammary stem cells: implications for studies of mammary development and carcinogenesis
}

\author{
Max S Wicha
}

Comprehensive Cancer Center, University of Michigan, E. Medical Center Drive, Ann Arbor, Ml 48109-0942, USA

Corresponding author: Max S Wicha, mwicha@umich.edu

Published: 23 August 2006

This article is online at http://breast-cancer-research.com/content/8/5/109 (c) 2006 BioMed Central Ltd
Breast Cancer Research 2006, 8:109 (doi:10.1186/bcr1540)

performing serial dilutions as well as transplanting single marked cells that were confirmed by visual inspection they calculated that at least one out of 64 cells bearing the phenotype Lin-CD29hiCD24+ is a stem cell, as defined by its ability to reconstitute an entire mammary gland.

Studies in haematopoietic stem cell biology have been greatly facilitated by the development of suitable animal models in which a single haematopoietic stem cell can reconstitute the entire haematopoietic system of a lethally irradiated mouse [3]. Until the present time, comparable in vivo models did not exist for epithelial stem cells. The study of Shackleton and colleagues [1] provides the first model system in which the epithelial components of an entire organ can be generated in vivo from a single cell. Both the studies of Shackleton and colleagues [1] and similar studies reported by Stingl and colleagues [4] demonstrate that these cells also display the second defining property of stem cells, the ability to self-renew. To demonstrate this, they performed serial transplantation of mammary repopulating units, calculating that a single mammary repopulating cell is capable of executing at least ten symmetrical self-renewal divisions.

Recent studies have suggested the existence of stem cells in the human mammary gland similar to those in the rodent. These studies have largely consisted of in vitro characterization of cells that could give rise to multiple lineages. We demonstrated that non-adherent mammospheres are highly enriched for cells with stem and progenitor cell properties [5]. The ability to transplant human mammary cells into the rodent mammary gland was advanced by the work of Kuperwasser and colleagues [6]. They demonstrated that human mammary epithelial cells could be grown in fat pads of NOD/SCID mice that were humanized by human mammary stromal cells. Building on this work, we have recently reported that mammospheres can regenerate human mammary glands in such a model [7]. These studies highlight the importance of stromal-epithelial interactions in regulating

gland they used the Rosa-26 mouse carrying a LacZ transgene, which allows for tagging of donor cells. By 
mammary stem cell self-renewal and differentiation. These interactions define a stem cell 'niche'. This niche is thought to be composed of both cellular as well as extracellular elements. It is postulated that stem cells receive paracrine signals from 'niche' cells that regulate stem cell behavior, including self-renewal and differentiation. The nature of the stem cell 'niche' that regulates behavior of normal and malignant mammary stem cells has recently been reviewed by Bissell and colleagues [8] and Li and colleagues [9]. The ability to transplant both murine and human cells into such a 'niche' should allow the further elucidation of key regulatory pathways for stem cell self-renewal and lineage specific differentiation.

The isolation and characterization of mammary stem cells also has important implications for understanding mammary carcinogenesis. Recent studies in the mammary gland and other organs have given impetus to the 'cancer stem cell hypothesis', which has two interrelated components. The first is that cancers arise from stem cells or their immediate progeny, and the second is that tumors contain a hierarchy of cells, including 'cancer stem cells' that drive tumorigenesis [10]. The study of Shackleton and colleagues [1] supports such a model. They examined the percentage of cells expressing the stem cell phenotype Lin $^{-} \mathrm{CD} 29^{\text {hi }} \mathrm{CD} 24^{+}$in MMTV-wnt transgenic mice. It has previously been shown that these mice develop carcinomas containing cells that display markers of both epithelial and myoepithelial lineages [11]. Shackleton and colleagues report that there was a 6.4-fold increase in the absolute number of cells bearing the stem cell phenotype in these mice. Wnt signaling has been shown to play a role in the self-renewal of several normal stem cells [12]. Interestingly, when Shackleton and colleagues transplanted $\mathrm{CD} 29^{\text {hi }} \mathrm{CD} 24^{+}$cells from these transgenic mice into cleared fat pads of wild-type recipients, the recipients produced hyperplastic outgrowths. This is consistent with the stem cell model in which perturbation of the self-renewal of stem cells gives rise to stem cell expansion and hyperplasia, which in turn provides targets for further transforming events [10]. Indeed, we have found that disruption of Hedgehog signaling in normal human mammary stem/progenitor cells results in the generation of ductal hyperplasia when these cells are transplanted into the humanized cleared fat pads of NOD/SCID mice [7]. Interestingly, expansion of the stem cell compartment was not seen in MMTV-neu mice, which develop luminal tumors. These studies suggest that, while MMTV-wnt affects a primitive mammary cell, MMTV-neu affects a more committed epithelial specific progenitor. These studies are also consistent with our recent characterization of stem cells in human breast cancer, which are characterized as CD 44 ${ }^{+} \mathrm{CD} 24^{\mathrm{lo}} \mathrm{Lin}^{-}$[13]. Both Shackelton and colleagues and Stingl and colleagues localized the majority of mammary repopulating cells to the basal compartment in the normal gland, while human breast cancer cells express CD44, a basal marker [13]. This suggests that there may be a link between normal and tumorigenic breast stem cells. In addition, transformation of different mammary stem or progenitor cells may account for the different molecular subtypes of breast cancer detected in molecular profiling studies [14]. It remains unclear whether markers utilized to identify normal and malignant mammary stem cells play a functional role. CD29 and CD49 recognize alpha- 6 beta- 1 integrin, a molecule that has also been described as expressed in other stem cells. This integrin may play a role in anchoring stem cells in the stem cell 'niche'. CD44 is a receptor for haluronic acid, which has been shown to play a role in tumor migration and metastasis [15]. CD24 has recently been described as a negative regulator of CXCR4, a cytokine receptor important in facilitating breast cancer metastasis [16]. Interestingly, although the studies of Shackelton and colleagues suggest that murine repopulating cells are CD24+, more recent studies by this group and others have suggested that high levels of CD24 are expressed on luminal precursors, whereas an intermediate level of expression is found on more primitive mammary repopulating cells [17]. In the studies by Shakelton and colleagues, as well as our own studies, cells displaying lineage specific markers were eliminated to further enrich the stem cell populations. Together, these studies suggest that there are important similarities between markers expressed by both normal and tumorigenic mammary stem cells. Furthermore, these markers may play a functional role in stem cell behavior.

The further identification of markers that identify cells at different stages of mammary development should greatly facilitate our understanding of normal development and carcinogenesis. An understanding of the biology of the cells that drive tumorogenesis has the potential to lead to new therapeutic approaches for breast cancer.

\section{Competing interests}

MW is a consultant for and has financial holdings in OncoMed Pharmaceuticals.

\section{Acknowledgements}

MW is supported by NIH grant CA101860, DoD BC030214, and University of Michigan Cancer Center Support Grant 5P53CA46592.

\section{References}

1. Shackleton M, Vaillant F, Simpson KJ, Stingl J, Smyth GK, Asselin-Labat ML, Wu L, Lindeman GJ, Visvader JE: Generation of a functional mammary gland from a single stem cell. Nature 2006, 439:84-88.

2. Kordon EC, Smith GH: An entire functional mammary gland may comprise the progeny from a single cell. Development 1998, 125:1921-1930.

3. Osawa M, Hanada KI, Nakauchi $\mathrm{H}$ : Long-term Iymphohematopoietic reconstitution by a single CD34- low/negative hematopoietic stem cell. Science 1996, 273:242-245.

4. Stingl J, Eirew P, Ricketson I, Shackleton M, Vaillant F, Choi D, Li $\mathrm{HI}$, Eaves CJ: Purification and unique properties of mammary epithelial stem cells. Nature 2006, 439:993-997.

5. Dontu G, Abdallah WM, Foley JM, Jackson K, Kawamura M, Clarke $\mathrm{M}$, Wicha $\mathrm{M}$ : In vitro propagation and transcriptional profiling of human mammary stem/progenitor cells. Genes Dev 2003, 17:1253-1270. 
6. Kuperwasser C, Chavarria T, Wu M, Magrane G, Gray JW, Carey L, Richardson A, Weinberg RA: Reconstruction of functionally normal and malignant human breast tissues in mice. Proc Natl Acad Sci USA 2004, 101:4966-4971.

7. Liu S, Dontu G, Mantle I, Patel S, Ahn N, Jackson K, Suri P, Wicha $\mathrm{M}$ : Hedgehog signaling and $\mathrm{Bmi}-1$ regulate selfrenewal of normal and malignant human mammary stem cells. Cancer Res 2006, 66:6063-6071.

8. Bissell MJ, Labarge MA: Context, tissue plasticity, and cancer: are tumor stem cells also regulated by microenvironment? Cancer Cell 2005, 7:17-23.

9. Li L, Neaves WB: Normal stem cells and cancer stem cells: the niche matters. Cancer Res 2006, 66:4553-4557.

10. Wicha M, Liu S, Dontu G: Cancer stem cells: an old idea-a paradigm shift. Cancer Res 2006, 66:1883-1890.

11. Li Y, Welm B, Podsypanina K: Evidence that transgenes encoding components of the Wnt signaling pathway preferentially induce mammary cancers from progenitor cells. Proc Natl Acad Sci USA 2003, 100:15853-15858.

12. Lu S, Dontu G, Wicha MS: Mammary stem cells, self-renewal pathways, and carcinogenesis. Breast Cancer Res 2005, 7:8695.

13. Al-Hajj M, Wicha MS, Benito-Hernandez A, Morrison SJ, Clarke MF: Prospective identification of tumorigenic breast cancer cells. Proc Natl Acad Sci USA 2003, 100:3983-3988.

14. Dontu G, El-Ashry D, Wicha MS: Breast cancer, stem/progenitor cells and the estrogen receptor. Trends Endocrinol Metab 2004, 15:193-197.

15. Draffin JE, McFarlane S, Hill A, Johnston PG, Waugh DJJ: CD44 potentiates the adherence of metastatic prostate and breast cancer cells to bone marrow endothelial cells. Cancer Res 2004, 64:5702-5711.

16. Schabeth $H$, Runz $S$, Joumaa $S$, Altevogt P: CD24 affects CXCR4 function in pre- $\beta$ lymphocytes and breast carcinoma cells. J Cell Sci 2006, 119:314-325.

17. Asselin-Labat ML, Shackleton M, Stingl J, Vaillant F, Forrest NC, Eaves CJ, Visvader JE, Lindeman GJ: Steroid hormone receptor status of mouse mammary stem cells. J Natl Can Inst 2006, 98:1011-1014. 